\title{
A COMPREENSÃO DA RELIGIÃO ATRAVÉS DA TRAGICIDADE DO VERDADEIRO EM HEGEL:

\author{
uma introdução à existência
}

\author{
THE UNDERSTANDING OF RELIGION THROUGH \\ THE REAL TRAGEDY IN HEGEL: \\ an introduction to the existence
}

Harley Juliano Mantovani ${ }^{(*)}$

\begin{abstract}
RESUMO
Neste texto, buscamos compreender de que modo o trágico, como pensamento, apresenta um monismo como ontologia anterior da Vida. Em seu infinito processo de constituição, essa ontologia anterior é uma ciência do caminho seguro para a avaliação da necessidade científica do processo dialético através do qual uma filosofia da religião, se quer ser autêntica, deve morrer na Lógica que guarda as condições de uma existência verdadeira sobre o sepulcro vazio de Deus. Foi o nosso objetivo entender como esse vazio, ao mesmo tempo trágico e místico, recupera o sentido como vida e a vida como prática do finito.
\end{abstract}

PALAVRAS-CHAVE: Hegel. Verdadeiro. Religião. Trágico. vida.

\section{ABSTRACT}

In this text, we search to comprise of which way the tragic, like thought, present a monism like prior ontology of Life. In your endless process of constitution, that prior ontology is a science of firm way for the analysis of scientific necessity of dialect process through of which a philosophy of religion, if want to be authentic, must to die out in Logic which shelter the conditions of a true existence upon the emptiness holy of God. Was the our aims to understand as that emptiness, at the same time tragic and mystical, recover the sense like life and the life like practice of finite.

KEYWORDS: Hegel. True. Religion. Tragic. Life.

\footnotetext{
(*) Mestre em Filosofia pela Universidade Federal de São Carlos; Professor dos Cursos de Filosofia e de Teologia da Faculdade Católica de Uberlândia. E-mail: harleybrief@yahoo.com.br
} 


\title{
INTRODUÇÃO
}

\author{
Não me espantaria se tivesse Eurípedes razão em dizer \\ "quem sabe se viver é estar morto, e estar morto é viver". Talvez \\ estejamos realmente mortos (...), ouvi de um sábio que \\ presentemente estamos mortos e nosso corpo é uma tumba. \\ Platão, Górgias, 492e - 493a
}

A natureza de "introdução" desse texto se refere e se limita à ideia geral do percurso fenomenológico de constituição de uma ciência do processo de reunificação a si do Logos através do questionamento das verdades puramente formais e estáveis, e não alcança e não adentra, portanto, a Ciência do Logos ou do delírio e embriaguez do Verdadeiro.

Tivemos o propósito de demonstrar a tragicidade da autocontradição essencial do Verdadeiro, que tanto se manifesta nele, quanto manifesta o movimento dialético de inseparabilidade entre o infinito e o finito, entre Deus e o mundo, entre a identidade e a contradição e, neste sentido, defendemos que Hegel não pode ser definitivamente considerado como o simples prolongamento sem discussão da metafísica ontoteológica, como admitiu Guinzo (1986, p 8) $)^{1}$, entre outros termos, porque a lógica de Hegel não é uma ciência do vazio da forma, e tem por conteúdo esse ser eterno que ele mesmo denomina Deus ${ }^{2}$ - ou o retiro de si pelo qual o homem se cria e reconhece a sua existência buscando esse ser eterno que não é e que dissolve toda condicionalidade rumo a um fundo negativo pré-ontológico de uma vida que escapou - e foi mesmo negligenciada - por aquela metafísica que, desde o seu nascimento, não soube o que é um monismo verdadeiramente absoluto que se instauraria com a morte de Deus como fundamento do sentido das práticas comunitárias (GABRIEL, 2011). Em Hegel, o Verdadeiro, que encarna na comunidade que por ele vive, não é separado do fazer-se prático do sentido, de tal forma que a vida comunitária é o seu próprio sentido, pelo qual ela se autojustifica e é julgada.

Sua tragicidade significa que o Verdadeiro não é sem seu vir-a-ser, que propriamente se põe sempre adiante daqueles que o buscam. Busca que começa, de fato, no momento em que compreendem que não há mais términos, quando

\footnotetext{
${ }^{1}$ Esse posicionamento encontra-se na Apresentação que o autor faz a El concepto de religión de Hegel e que tem por título En torno a la filosofía de la religión de Hegel.

${ }^{2}$ Ver STEIN (2002).
} 
não esperam mais pelos términos e, enfim, quando realizando-a concretamente transferem da arte para a existência, a tragicidade cuja essência Hegel recupera e revivifica em seu elemento conceitual de dissolução de toda transcendência metafísica e teológica. E isto significa reconhecer ao processo absoluto da mudança circular sem substrato intrínseca ao Verdadeiro a sua fecundidade criativa originária que é a própria criação de uma vida cuja fertilidade conceitual consiste no retorno a si do que esteve sempre junto de si em sua própria alienação e estranhamento trágicos como as raízes e a seiva espirituais do Logos absoluto, primeiro e último, que não começa e não termina, que não é nada a não ser o puro pensamento se pensando no desassossego da sua essência ou o próprio retirar-se fecundande de si de Deus consigo mesmo reencontrado no mundo, na existência e na vida daquele que busca esse retiro no qual o entrar é o sair de si e a compreensão de que o se perder necessário pondo-se diante do nada é também a oposição a si como reencontro consigo e superação de si. Nesses termos, a tragicidade do Verdadeiro quer dizer a generatividade dialética e místico-racional do Logos pós-teológico do Saber absoluto? Ou, em última instância, como pode o Saber não ser apenas vida e uma Vida não apenas vivente?

\section{A COMPREENSÃO DO SUJEITO E A CRÍTICA DA RELIGIÃO SEGUNDO A VERDADE DA RELAÇÃO}

Enquanto verdadeiro e ultimamente justificado pelo sistema, o sujeito não é mais apenas substância (HeGel, 2008, p. 34), e assim ele se desvencilha da imediatidade do saber e do ser que, sob este viés, têm uma identidade anterior ao processo de constituição do verdadeiro a partir e através das suas relações futuras e sempre novas que, no entanto, já se encontram nele, não na forma de uma efetividade inata, e sim, como uma oculta e fértil ausência de limites. Não apenas a verdade do sujeito - que já existe enquanto cidadão da metafísica da substância que se compreende definitivamente pela identidade não relacional de si consigo mesma - mas o próprio sujeito só são reais ou objetivamente universais na relação. Então é por meio desta que será preciso pensar e compreender uma nova identidade para o sujeito em sua efetividade. Ao quebrar deste modo a inércia e a indiferença abstrata da substância, o nascimento do sujeito é também a passagem para uma nova vida ${ }^{3}$ - que já estava na subs-

\footnotetext{
${ }^{3}$ Esta é a vida do Conceito, que é geração para além da vida, ou uma vida que é geração sempre em sua gênese ou continuamente genética. O Conceito é o retorno e a vivência da geração não vital.
} 
tância como outra que esta -, na qual o sujeito "é o movimento do pôr-se-a-simesmo, ou a mediação consigo mesmo do tornar-se outro" (HEGEL, 2008, p. 35), e cabe dizer ainda que, para Hegel, "só essa igualdade reinstaurando-se, ou só a reflexão em si mesmo no seu ser-Outro, é que são o verdadeiro” (2008, p. 35). Em sua autoposição, o sujeito reinstaura a igualdade como alteração reflexiva que explicita a necessidade do se tornar do sujeito que o media consigo mesmo. Com isto, ao se recusar se tornar, o sujeito se separa de si mesmo e não assume a responsabilidade pela busca longa e árdua da sua verdade de vir-a-ser de si mesmo que culmina em uma obra cujo autor se ausentou na cumplicidade com o desaparecimento.

Essa busca é um retorno à simplicidade da reconciliação do círculo que resulta de si mesmo já em seu começo e que assim se realiza como um repouso que movimenta ou simplesmente como inquietude. E essa inquietude é justamente o $\mathrm{Si}$, o sujeito, o resultado que a si mesmo retornou depois do cultivo do seu próprio desaparecimento fértil e contrário à sua abstração. Esse retorno é o vir-a-ser desenvolvido e a realização da efetividade do Si que é então "igualdade e simplicidade, consigo mesmas relacionadas” (HeGel, 2008, p. 35). Eis a relação que constitui e que identifica o sujeito a despeito ou através de quaisquer outras relações que porventura se queira vê-lo entregue de acordo com o desenvolvimento da consciência de si mesmo ${ }^{4}$. O sujeito é fundamentalmente a relação da igualdade e da simplicidade consigo mesmas anteriormente a quaisquer outras relações derivadas desta permanência na simplicidade da igualdade a si dele mesmo em seu se tornar. Ele se relaciona com a sua própria igualdade e simplicidade enquanto a mediação mesma que é então uma relação real anterior às relações e possibilitadora destas ${ }^{5}$. Nesses termos, em última instância,

${ }^{4}$ Do mesmo modo que o puro pensamento se pensando em seu ser-outro (ou o Logos como o Conceito que se sabe na objetividade da subjetividade da sua reflexão), está nas categorias do entendimento finito sem ser o puro fenomênico como conteúdo último do saber de si, essa Relação não se reduz às relações nas quais o $S i$ ainda não é idêntico ao Ser, pois, ela sendo vida e oposição absoluta da vida a si, é o pensamento vivo do Absoluto, é a reflexão do Logos em si mesmo como outra vida, como vida onto-lógica para a qual a essência é negatividade, é perpétua transcendência de si, ou seja, a minha essência me nega, ela é minha morte, e portanto, o que rege a Relação na qual o meu ser espera pelo meu si, já que o Si é o Sim retirado do Não, é uma oposição afirmativa, e a Singularidade cuja autenticidade é a própria identidade da identidade e da não-identidade ou a alienaçã̃o que se aliena em si mesma.

${ }^{5}$ Esta Relação irrelativa é o próprio Espiritual (ruptura que é também mediação, alienação que é também cultivo), pois, conforme Hegel, "só o espiritual é o efetivo: é a essência ou o em-si-essente: o relacionado consigo e o determinado; o ser-outro e o ser-para-si; e o que nessa determinidade ou em seu ser-fora-de-si permanece em si mesmo - enfim, o [ser] espiritual é em-si-e-para-si" (2008, p. 39). O saber-se desta relação em seu desenvolver-se como conceito puro será a Ciência, que 
não há sujeito ou identidade que preceda a relação responsável pela dissolução da fixidez do substrato da subjetividade predicativa e inefetiva.

De acordo com o sobredito, essa Relação irrelativa é a ausência de limites finitos que chama o indivíduo para deixar a comodidade ilusória do seu ser e buscar cumprir o destino da sua realização histórica através da qual ele atravessa e perscruta a si mesmo com a nostalgia e a saudade das suas lembranças não psicológicas que lhe são mais caras. Essa Relação não é apenas uma voz que não é sua, uma palavra que ele não diz, ou um sentimento mais puro do que os seus sentimentos, nela estão re-unidos a vida e o pensamento, a ação e a razão, a morte e a ressurreição, ela é um profundo e absoluto Sim como uma realidade já retornada a Si enquanto Negação das suas próprias negações. A Relação é um sim que é negatividade pura ou a própria superação de um niilismo que termina no nada abstrato e não dialético. Esse niilismo é a crença em um triunfo e repouso finais dos que não souberam desesperar com coragem inabalável, esse niilismo é a saída cansada desse caminho infinito, prático-racional e puramente negativo, ao final do qual estamos esperando por nós mesmos. Em suma, essa Relação irrelativa como ausência de uma realidade dialeticamente familiar é um processo cujo percurso é um avançar que sai do retorno e um retornar que sai do avanço em direção a um momento em que, ao estarmos distantes de nós mesmos, jamais estivemos tão próximos. A verdadeira distância e a verdadeira proximidade são como o resultado que só depois de efetivado se encontra a si mesmo no começo, ou como a igualdade e a simplicidade sem nada fora das suas relações, e o que não tem nada fora da sua própria diferenciação (Unterscheidung) consigo mesmo pela qual ele permanece igual e simples e dissolve assim a separação (Trennung), é o Absoluto enquanto conceito omnicompreensivo que tem como sua a vida divina extraída da morte de um Deus que morreu para moralizar o mundo e para libertar a Comunidade ${ }^{6}$ que precisava desta morte para sair do seu ensimesmamento imediato e adquirir o saber da sua consciência de si já realizada como retorno à familiaridade interior ao indivíduo e subjacente tanto à identidade idêntica

também deverá dar conta dessa prévia reciprocidade da inquietude e do repouso intrínseca ao sujeito.

${ }^{6}$ É claro que resta a pergunta: que espécie de comunidade é esta que assim se realiza e que vive a vida de um Deus morto? Ela é o Reino do Espírito que, instaurado pela morte e ressurreição de Cristo, é renovação perpétua da subjetividade e vida que se renova perpetuamente (GUINZO, 1986, pp. 23-4) através da interrogação constante "sobre as condições de possibilidade do mundo simbólico" (GABRIEL, 2011, p. 536) que essa comunidade renovada toma como sua residência. 
da substância quanto à identidade indiferenciada alcançada através das relações imediatamente vazias e insatisfatórias.

Essa Relação irrelativa, ou o Verdadeiro, é a Comunidade mais familiar e mais próxima do indivíduo do que o seu pai e a sua mãe e do que o seu próprio Eu. É em razão disto que não podemos dizer que, em certo sentido, a religião é a expressão mais excelente desta Relação, caso contrário não precisaríamos deste Deus-relação cujo reino está em nosso não-Eu, em nossa alteração qualitativa por meio das nossas açốes e das nossas experiências de extrair das nossas renúncias a renovação das nossas forças e a coragem para compreendermos a instabilidade infinita das nossas antigas conviç̧ões e verdades. Para nos relacionarmos verdadeiramente, para alcançarmos a comunidade Real, e para vivermos a vida da Relação omnicompreensiva em nossos pensamentos, devemos, portanto, ir além da religião que impede o nosso aperfeiçoamento, aqui, neste mundo, e que nos leva ao comodismo adulterante da fé por postular a realidade de um mundo sempre mais além no qual se encontraria conforto, repouso, paz e felicidade de um final que não é retorno, distinto e separado do começo, e por conseguinte, apenas abstratamente distante e estranho. E isto significa irmos além das representações de uma religião que separa a unidade absoluta da sua própria manifestação (Wirklichkeit), e que desta forma promove a dissociação entre a substância da cidade e a substância do espírito, instaurando, com isto, um infinito objetivo separado (que tem em germe a interiorização do teológico, do político e do social na forma particular da liberdade na alma) que de si exclui a morte como símbolo de um divino forte e realmente absoluto.

Nesses termos, na mera consciência das suas representações a religião é uma relação em si mesma que ainda não se sabe em seu ser para si, e deste modo se encontra em uma imediatidade e empiricidade que tanto influem quanto se restringem à afetividade humana, e a uma linguagem alegórica, metafórica e derivada, condizente com essa afetividade psicológica, que talvez por medo ou por ceticismo, ainda não fez e arrogantemente se recusa a fazer a travessia da sua contingência para a sua necessidade. Ao se compreender desta forma como não acesso à Relação que a descortina dela mesma, a religião não nos possibilita sermos sujeitos, como se a nossa própria história fenomenológica lhe fosse uma ameaça, e por isto somos para ela substâncias que continuam e cultivam a infertilidade herdada de um infinito mal compreendido e adulterado, de um infinito ruim inessencial e sem verdadeira infinitude. Nessas condições, em última análise, a religião não apenas não tem infinito como nos bloqueia o acesso 
ao infinito verdadeiro. Isto significa uma busca equivocada de sobrevivência da religião que, imobilizando e eternizando a infelicidade da consciência, excomunga de si mesma a dialética e procura se manter e se conservar através de um professar e de uma prática que não passam de uma mimesis adulterada, distante e enfraquecida, pela qual os seus próprios membros se autoconservam nos limites substanciais, alegres e confortáveis das suas individualidades, então transformadas em personagens que resistem em fazer a passagem espiritualizante do cômico para a tragédia do Verdadeiro não mais estetizada 7 . Pois isto pressupóe retirar as máscaras teatrais e deixar de ser pessoa para ser a pura subjetividade dos símbolos dilacerantes e fortalecidos pela morte espiritual que constitui o elemento do pensar que desce ao ser-aí (Dasein), saindo das significações interiores das palavras vazias rumo à efetividade como a própria negatividade da essência eterna do saber de si mesmo do conceito que, nessas condiçôes "é o Verbo que, pronunciado, deixa atrás o pronunciante extrusado e esvaziado" (Hegel, 2008, p. 515) cuja renúncia é audição do seu desaparecimento mesmo. "E o ser-aí do Verbo é somente esse ouvir-se a si mesmo” (HeGel, 2008, p. 515) que traduz o verdadeiro e efetivo justamente nesse "movimento que gira dentro de si" que reflete o é-aí do Deus revelado acessível no puro saber especulativo, "e esse saber especulativo é o saber da religião revelada" que é um modo de apreensão do processo em que a essência absoluta descida de sua simplicidade eterna se torna, ao mesmo tempo, essência suprema com uma leveza não abstrata e sem infinito além. "Essa encarnação da essência divina [...] é o conteúdo simples da religião absoluta" (HeGel, 2008, p. 509), na qual a essência se sabe como espírito e nesse saber de si temos a identidade da carne e do espírito.

\section{AS CONDIÇÕES DA RELIGIÃO VERDADEIRA E A TRAGICIDADE DO MOVIMENTO DO VERDADEIRO}

A religião verdadeira, que não substancializa a infelicidade da consciência fazendo dela o falso peso de um infinito abstrato e insustentável que ela aju-

\footnotetext{
${ }^{7} \mathrm{Na}$ dialética da religião como um momento vivo interior ao autodinamismo do Absoluto ocorre a superaçã̃o da tragicidade já dentro da religião da arte e, por isto, a religião revelada não conhece a tragicidade estética ou o trágico circunscrito a um gênero estético. Isto não significa, no entanto, que Hegel abandona, ultimamente, a tragicidade, ele apenas retira a tragédia da sua restrição à arte, concedendo-lhe os limites existenciais de uma vida verdadeira, ou seja, Hegel apenas retira-a da sua artisticidade que estava mais distante da verdade do trágico ou da tragicidade do Verdadeiro, do que a religião cristã cuja revelação é a manifestação mesma da absolutidade que dispensa a arte.
} 
daria a carregar, ela mesma completamente destituída da consciência de si do espírito essencializado, é a que irá se alienar na presença histórica da unidade recuperada entre a essência e o Si, entre o divino e a existência, exortando-nos a uma prática de renúncia das nossas certezas desprovidas da unidade essencial, e ao cumprimento dialético de um destino trágico cuja dor, no entanto, é já manhã da unidade da essência e da consciência de si como "revelação do Cristo, seu nascimento, sua vida, sua morte e sua ressurreição na comunidade" (Hyppolite, 2003, p. 587), que assim herda e deve se fundamentar não na sexta-feira Santa histórica, mas na especulativa, ou seja, não em suas representações da história sagrada, e sim, no Conceito enquanto movimento espiritual de ser igual a si mesmo em seu ser-outro. Este movimento, que é o do Verdadeiro pelo qual a consciência de si nasceu, morreu e ressuscitou na universalidade de um não-Eu coletivo e real, é também o da instauração pré-representativa de uma Comunidade fundamental que se realiza através da superação - desta vez na ordem da vida espiritual absoluta - das relações naturais e representativas entre pai e filho como metáforas da Relação conceitual entre o infinito e o finito, entre o ser e a essência, enfim, entre o Logos e a Natureza. Em sua verdade, a religião deve propiciar o saber especulativo de si da comunidade religiosa que, entretanto, "não é a forma mais alta do saber de si do espírito" (Hyppolite, 2003, p. 592), pois, ela se relaciona com um Deus desaparecido que já não é, que é um ter-sido interiorizado (Erinnerung) como recordação comum como relação empobrecida porque desprovida do saber de si do espírito prévio à Vorstellung ${ }^{8}$. Esta não reúne a comunidade em torno de uma verdadeira familiaridade, que é irredutível à naturalização das relações, que nos impede de acedermos não apenas a nós mesmos enquanto sujeitos em processo, mas também, à verdade da própria religião igualmente sujeita à Aufhebung que também é revelação do defeito da união do ser e do pensar (HeGEL, 2008,p. 513) que reflete uma cisão na essência espiritual ainda não reconciliada como conteúdo verdadeiro na figura de sua verdade de ser vida em seu "refletir-se dentro de si mesmo" como Si efetivo ou ser-aí sabido pela religião revelada "que sabe Deus como pensar, ou pura essência, e esse pensar como ser e como

\footnotetext{
${ }^{8}$ A natureza abstrata do pensamento separado e ainda sem o saber de si que caracteriza a unidade entre o Conceito e sua manifestação. Essa representação (Vorstellung) quer dizer o distanciamento de Deus, o enfraquecimento e o esvaziamento do divino.

9 Trata-se do processo fenomenológico e dialético, intrínsecamente científico e necessário, de superação das inverdades e do abstracionismo especulativo, de explicitação e de conservação da essência, em que pese a realização da Ciência em que, finalmente, o Absoluto se sabe.
} 
ser-aí, e o ser-aí como a negatividade de si mesmo" (Hegel, 2008, p. 511). Eis a verdade da religião enquanto conteúdo para o conceito e não ainda o conceito como o seu próprio conteúdo.

$\mathrm{Na}$ verdade da religião, cada um de nós deve se fazer sujeito pondo-se nos caminhos incertos e arriscados através das suas próprias noites mais profundas, deste jeito retirando, da perda da sua identidade por esses caminhos, um modo de sobreviver no qual Deus, mesmo que ainda como essência abstrata, se faz consciência de si como homem verdadeiro não mais em mim, mas em Nós enquanto comunidade espiritual. Eis a realização da Reconciliação, o retorno a si da realidade, e por isto, a reconciliação não apenas do homem consigo mesmo, do homem com Deus, mas, sobretudo, do Deus com sua igualdade e simplicidade a si relacionadas já no elemento da sua verdade e da sua essência, que contribuímos para realizar quando nos entregamos sem máscaras à liberdade da Relação trágica com o Verdadeiro, que é o retorno da representação à consciência-de-si na forma autêntica da unificação do conceito, e que faltou à religião (Hegel, 2008, p. 534) destituída da operatividade prática do espírito ou do é-ai do Absoluto que abandonou a sua essência eterna (Hegel, 2008, p. 535) para se tornar o Agir do saber que, cultivando-se no risco constante do seu autojulgamento, então se dá realidade e transforma em vida o que, na religião, era apenas "conteúdo ou forma do representar de um outro" (HeGel, 2008, p. 536). É na inserção nesta Ação do puro saber como prática autorreflexia que a finitude encontra a sua autonomia e o seu juízo.

A recuperação do Verdadeiro em seu sólido e trágico otimismo e em sua realização ultimamente científica deve significar também e inevitavelmente a recuperação da finitude como processo essencial à dinamicidade do Ser absoluto que, para reunificar-se e totalizar-se, tanto necessita quanto salva a finitude, que anteriormente se pretendia autônoma em suas ações descontínuas e positivistas, mas, cuja autonomia não passava de uma arrogante, despreocupada e imediata satisfação das suas paixões e dos seus interesses contingentes como adulteração do desejo de autoconservação e como manutenção cômoda da identidade particular do seu eu. Ao passo que, em sua finitude, o eu é um estado de existência e deve, portanto, perecer, porém, esse perecimento como passagem e substituição do velho pelo novo, significa a própria infinidade se fazendo nesse processo de automodificação que antecipa e nos ensina sobre a essência. Olhado assim, com rigor, o perecer engendra o infinito, isto porque, segundo Marcuse, "o processo pelo qual uma coisa finita perece e, perecendo, 
se transforma em outra coisa finita que repetirá o mesmo processo, é um processo ad infinitum (...). O incessante perecer das coisas é, pois, uma negação igualmente contínua da finitude delas. É uma infinidade” (1969, p. 133). Ora, e esse dissolver da estabilidade do ser é o próprio vir-a-ser da essência enquanto movimento infinito de autorrealização contraditória do sujeito como fazer-se trabalho livre.

A liberdade da finitude é interior ao Verdadeiro que, em contrapartida, exige-lhe o sacrifício verdadeiro dos seus limites, sacrifício que é a própria transcendência de si dolorosa e sofrível pela qual a finitude se fortalece e se reveste de um otimismo não cético para resistir e adentrar na interioridade e na necessidade do movimento dilacerante do Universal, e assim se compreender, vir-a-ser aí espiritualmente e infinitamente postergando uma apenas possível satisfação última que não desespera, não pesa, não cansa, não aprisiona. Tal como o Verdadeiro retorna a si no aí do vir-a-ser da finitude, esta compreende que o renascimento da sua existência ou o reencontrar-se consigo mesma no elemento da essência se faz através da perda de si mesma no Verdadeiro, que para ela surge como um Pai que a libertará da recaída no desamparo e no desespero pusilânime que a conduzia ao nada abstrato não-dialético de nenhuma posição. O Nada precisa ser também posição, ou seja, o Não deve ser também um Sim. Em escala inferior, isto significa que a finitude renasce da sua morte no Verdadeiro como Outra vida que nela sempre esteve presente como unidade e realidade de todas as suas possibilidades anteriormente à satisfação. Como se nota, o conceito hegeliano de finitude nos é importante porque, com ele, Hegel "libertou as tentativas filosóficas de acesso à realidade, das poderosas influências religiosas e teológicas, que agiam mesmo sobre as formas leigas do pensamento no século XVIII" (Marcuse, 1969, p. 132), e mesmo reconhecendo que o ser finito é sem ser além das suas transformações e tem, pois, uma natureza ideal, este idealismo se identifica com a filosofia como um pôr em questão a verdade do estado determinado, ao invés de significar "que se deva buscar o verdadeiro ser em um Além sobrenatural, ou nas profundezas da alma humana" (MArcuse, 1969, p. 134). Temos uma filosofia idealista da finitude, e sem além e sem alma. Isto porque a consciência infeliz foi o "destino trágico da certeza de si mesmo". A infelicidade - que ao invés de gerar a cisão metafísica é já o começo da sua separação - "é a consciência da perda de toda a essencialidade nessa certeza de si" e, portanto, "é a dor que se expressa na dura palavra: Deus morreu" (Hegel, 2008, p. 504). Palavra cuja intimidade dolorosa 
carrega essa morte do abstrato como princípio e movimento de infinitização da finitude.

O Verdadeiro hegeliano - ou o Espírito na vida do seu saber em seu conceito real - não implica na desvalorização e na ruptura pobre, raivosa e vingativa com a finitude. Deste modo recuperada, a finitude é doravante infinitamente finita, ou seja, libertada do fim determinado (que a negava abstratamente e) pelo qual seu otimismo ingênuo não passava de uma crença no término, a finitude recebe das mãos do Verdadeiro (e não apenas das suas próprias mãos e ações) sua essência como sua mortalidade, não apenas inseparável, mas igualmente revivificadora da sua existência. $\mathrm{O}$ Verdadeiro não me nega a mortalidade como minha essência, ele não separa minha essência e minha existência, e não afirma ultimamente uma imortalidade separada e determinada que do exterior satisfaria, qual um fim alcançado, a inquietude do infinito que me habita e me conduz para uma compreensão e um saber da Vida universal que adentro e na qual me reencontro qualitativamente renascido ao não me negar e não evitar o dilaceramento absoluto. O Espírito vive enquanto Retiro da minha vida pelas mesmas razões segundo as quais "sem o mundo, Deus não é Deus” (Hegel, apud Guinzo, 1986, p. 18).

A negação do mundo como momento vivo e de vida transformada no interior do movimento dialético por meio do qual "Deus não é Deus", é a negação da mortalidade então restringida a uma finitude destituída de infinitude, como se o avanço não fosse retorno. Essa negação é equiparável não ao medo do erro, mas antes, ao medo do Verdadeiro ${ }^{10}$ que nos exige que não nos atemorizemos ante a morte e busquemos uma conservação intacta da devastação, mas, pelo contrário, que saibamos viver uma vida que suporta a morte e nela se mantém, que é a Vida do espírito enquanto a verdade encontrada e retirada de dentro do seu próprio dilaceramento absoluto ${ }^{11}$. E este não é um estado alcançado, e sim, um longo e árduo caminho pedagógico de perda de nós mesmos no qual aprendemos a desesperar e a ver no desespero (Verzweilflung) a saída violenta e parturiente da inverdade de toda a nossa vaidade abstrata.

O desespero supra-cético nos arranca para fora de nós mesmos quando não há mais vida natural em seu ser-aí imediato, transformando a consciência em seu conceito que é justamente esse ser-arrancado-para-fora ou, simplesmente, sua morte enquanto um "ir além do limitado, e - já que este limite lhe

\footnotetext{
${ }^{10}$ Ver HEGEL, 2008, p. 72-3.

${ }^{11}$ Ver HEGEL, 2008, p. 44.
} 
pertence - é o ir além de si mesma” (HeGEL, 2008, p. 76), também entendido como um "ir contra" a naturalidade do movimento do pensamento, das ações e dos sentimentos, que criam para si instituições que se cristalizam e nas quais a consciência se fixa comodamente e se atrofia na recusa da violência própria da sua inquietude e do processo de se produzir a si mesma sem um estado final de descanso como uma promessa responsável pelo seu pseudo-otimismo ${ }^{12}$. Ora esse "ir contra" é a própria realização do círculo da realidade que requer um pensamento que avance voltando contra si mesmo para não ser outra coisa que esta Relação ou esta Vida já convertida em seu avesso que é um atrás-adiante que fundamenta e sublima a busca pelo Verdadeiro. Trata-se de uma sublimação na medida em que a verdade exige a irrupção do sujeito enquanto vida que se coloca contrária aos fatos (MArcuse, 1969, p. 149), e que deste modo se torna sinônimo de trabalho livre como forma genuína do Ser verdadeiro. Por meio desta sublimação que faz de um trabalho a vida mesma, o pensamento não tem mais sujeito, pois, não mais existe outro sujeito que o pensamento que se realiza como essa liberdade autocompreensiva de um sujeito para o qual sua identidade não está fora do seu trabalho conceitual. O que se nos apresenta é a sublimidade - a capacidade de sublimar - do fundamento em seu automovimento autosuficiente, pois, ele opera a conversão como um "ir contra a si" da individualidade que assim se supera desvirando-se nesse avanço para o antecipado que é, evidentemente, a mortalidade e a morte mesma. E, neste sentido, a filosofia coincide com a morte, na medida em que ela é esse pensamento cuja oposição a si é sua vida que vem à luz através do dilaceramento dos seus limites solipsistas. Em sua dupla direção, por um lado, a filosofia "vem a ser um avanço processual para o antecipado, e por isso tem um sentido ascendente" (Guinzo, 1986, p. 41), conforme acentua Guinzo, que também destaca que a filosofia atua retrospectivamente, de forma que o seu antecipado aparece como último, "como fundando tudo o que o precede". Nesses termos, é forçoso que a consciência resista à angústia desse caminho rumo à verdade e busque salvar o que nesse caminho ela está ameaçada de perder. E o que ela deve perder é o

\footnotetext{
${ }^{12}$ Próprio do homem que sequer se reconhece perdido à mercê dos fatos circundantes por se recusar entregar-se ao risco de ser livre em sua "atividade de compreender (Begreifen)" (MARCUSE, 1969 , p. 148) as potencialidades contraditórias que, ao invés de enfraquecê-lo e ser sinônimas de anomalia, fortalecem e transformam o mundo revelando-lhe a inversão da sua essência ou a essência como inversão da sua aparente harmonia. Herdeiro do protestantismo, esse homem apenas tem casa no reino interior da sua alma cuja fuga do miserável mundo social é, indiretamente, uma cumplicidade e uma acomodação à realidade social (MARCUSE, 1969, p. 25).
} 
seu "zelo ardente" por uma verdade vazia na qual se delicia o seu Eu árido e se satisfaz o seu entendimento que, afastado do exame da realidade do conhecer, conserva-se na fuga do Universal ${ }^{13}$.

O VERDADEIRO ENQUANTO VIDA: a superação da teologia e a apresentação da lógica como ontologia anterior da cientificidade da vida

A verdade da consciência deve surgir da violência que a consciência sofre e se impốe a si mesma, a violência da inquietude do ir contra, do se questionar e do se perder em suas experiências para, somente assim, nascer novamente e se reencontrar consigo mesma na distância de uma outra-Vida que sempre esteve nela como a medida da essência, da essência como medida das diferenciaçóes não-separatistas, da igualdade e da desigualdade, enfim, da necessidade do processo que revela que o saber é o Relacionar-se, é um ser para-um-Outro que constitui a experiência do Verdadeiro que contém a nadidade de todo o precedente, e neste vir-a-ser constante temos o saber da necessidade do surgir puro, da gênese interminada do novo ${ }^{14}$. Assim, segundo a necessidade desse caminho dialético pelo qual temos o saber como Ciência da experiência da consciência, alcançamos "o reino total da verdade do espírito", e isto nos ensina que, "a consciência, ao abrir caminho rumo à sua verdadeira existência” (Hegel, 2008, p. 82; grifo nosso), ressurgida do enfrentamento da fertilidade do desespero de si mesma, das suas convicções e verdades, "vai atingir um ponto onde se despojará de sua aparência", libertando-se da abstrata estranheidade a si idêntica. E precisamente neste momento, "a aparência se torna igual à essência", e não há mais um nada que empobreceria o mundo com uma cisão. A partir de então, resta-nos uma exposição que "coincide exatamente com esse ponto da ciência autêntica do espírito. E, finalmente, ao apreender sua verdadeira essência, a consciência mesma designará a natureza do próprio saber absoluto" (Hegel, 2008, p. 82; grifo nosso). Esta "ciência autêntica" do espírito - aquela que apreende sua verdadeira essência - não é a teologia da separação de Deus e da vida, do infinito e do finito, da essência e da aparência, que no entanto se apresentam reunidas numa outra-Vida não-teológica, na vida no reino total da

\footnotetext{
${ }^{13}$ Ver HEGEL, 2008, p. 76-7.

${ }^{14}$ Ver HEGEL, 2008, p. 77-81. O Conceito é um surgimento puro enquanto o nascimento contínuo do novo que é Vida. No Conceito alcançamos a pureza do surgir cuja aparência parece nem surgir e nem passar, e assim se nos entregando a pureza do surgimento perpétuo de uma Vida segundo o qual o novo é sempre gênese que termina os términos e que deste modo é Afirmação.
} 
verdade do espírito onde a consciência leva uma verdadeira existência segundo a natureza do Saber absoluto como ciência autêntica do espírito igualmente não mais restrito à consciência teológica de si. O Saber absoluto supra-racional - se falamos de uma razão deificada que ainda não morreu no seu Conceito real - é uma Nova-vida segundo uma verdade que não pode mais ser identificada com alguma realidade teológica (ou de alguma forma reificada).

Para Hegel, em última análise, a verdade não é separadamente divina e conservacionista e a razão não é uma espécie de deusa extática, na exata medida em que, para ele, Deus só se revela retirado no Conceito real cuja vida é um fluxo que se invertendo ainda reflui em si e para si, e através da qual podemos reconhecer uma misticidade racionalmente irrepresentável e uma recuperação do primordial e permanente caráter relacional do sagrado então fertilizado pelo Retiro de Deus ${ }^{15}$.

O Verdadeiro é pós-Deus, ou seja, sua misticidade racional quer dizer ainda uma Vida forte e saudável após a morte de Deus, que abala a operatividade lógica do pensamento moderno imobilizado em suas representações separadas do mundo e do fluxo não-biológico da vida fértil. Ao invés de parar em Deus como fundamento separado e condição última da fundamentação lógica do conhecimento - o que significaria estranhamente a elevar o Amor a status de Arkhé -, Hegel vai além desta recorrência inconfessada à teologia, e explicitando sua dialética e limites antitéticos intrínsecos, anuncia a necessidade científica da morte da teologia e a supera rumo a uma lógica mistica, que determina o ascetismo como entrega racional ao desvelamento da realidade lógico-linguística da criação enquanto elo carnal entre o pensamento e a realidade. Trata-se de encontrar a essência da Palavra (Logos, Verbum) no pensamento puro da Relação, da palavra que é acolhimento que não se faz sem violência, porque esta palavra é pura intimidade e, portanto, inocência absoluta e ultimamente racional. Sobre esse místico lógico, sobre esse viver a intimidade e a inocência absolutamente, expondo-se à violência desse ascetismo do conceito, eis como Gadamer nos apresenta tal inefabilidade:

\footnotetext{
${ }^{15}$ Retiro que é a vida de Deus em seu "jogo de amor consigo mesmo" que jamais foi uma recusa do sacrifício de si para negar o nada do seu outro numa verdadeira reconciliação pela qual não há repouso sem trabalho, pela qual a dor é já superação da infelicidade, e o rebaixamento é também alteamento (VIEILHARD-BARON, 2006).
} 
Quando Hegel procurou desvelar 'o lógico' [das Logische] como o elemento mais intimo da linguagem e apresentá-lo em toda a sua articulação dialética, ele tinba razão até o ponto em que via ai a tentativa de reconstruir de maneira pensante os pensamentos de Deus antes da criação - um ser antes do ser (2012, p. 114; grifo nosso).

Assim se esclarece a necessidade de superação da teologia, incapaz de ser uma pré-ontologia, incapaz de ser uma Ciência do pré-ser recolhido no Logos, recolhimento pensante que é também a morte do ser da qual é também ciência a Lógica, então intrinsecamente trágica, de uma forma que não conseguiu ser a Arte. Com isto, a arte não é, para Hegel, a melhor expressão do autoconhecimento de si da vida enquanto Desenvolvimento puramente conceitual, e este é precisamente o pré-ser considerado como o princípio fundamental da Lógica da Oposição que constitui a identidade anterior em sua totalidade última, cuja pura indeterminação retornada nos revela a identidade pré-ontológica - a de uma vida mais viva igualmente trágica e mística - dos opostos fundamentais, do ser e do nada ${ }^{16}$, que pré-são ao ser e ao nada cronológico-aparentes cujas identidades não absorvem a sua oposição absoluta. O pré-ser é, neste sentido, o puro conceito de Ser sem qualquer determinação, e através de tão absoluta destituição lógico-ascética, o que temos é o próprio Nada ${ }^{17}$. Em sua realidade lógica, a oposição é a operação mesma da reunificação espiritual através do dilaceramento que desaparece no Logos, o qual, exatamente por isto, não é sem caminhar pelo místico como um seu momento vivo e cuja vida mata todos os términos transcendentes e infinitos. E isto significa, para Hyppolite, que "a redução da filosofia à lógica, longe de conduzir a um formalismo, ou mesmo a um intelectualismo como frequentemente se reprovou a Hegel (...), conduz a uma espiritualização da lógica” (2003, pp. 602-3; grifo nosso). Que é uma filosofia da radical tendência ao seu outro do transcendental sem ser ontologia pura e simples.

A misticidade é lógica e a logicidade é a Vida do Verdadeiro. É neste sentido que a Fenomenologia do espirito enquanto ciência da manifestação que desaparece é explicitada por seu resultado já nela avançado antecipadamente, a saber, pela Lógica enquanto Ciência da Vida, pela Lógica que compreende em si o saber de si da Vida-retirada que se reflete em seu ser-outro, ou seja,

\footnotetext{
${ }^{16}$ Sobre esse Desenvolvimento conceitual como a vida essencial do Espírito e da Lógica como ciência desta dinamicidade, confira Stein (2002, pp. 76-82).

${ }^{17}$ Portanto, o pré-ser é o negativo, porém, esse não é igualmente um sim. O pré-ser é uma morte que é vida e uma vida que não é vida - assim autorreflexiva - a não ser ao atravessar e interiorizar a morte como um caminho necessário, essencial e fenomenológico de superação das suas nostalgias.
} 
na morte que ela traz em si e suporta. Nenhum Deus de nenhuma teologia é mais sinônimo e mais fertilizador da vida do que o místico lógico de Hegel. E nenhuma outra-Vida exigiu e mereceu tão dignamente a ciência da morte filosófica pelo Verdadeiro. Vivê-la é buscar a ciência de já ter sido julgado pelo deus e, portanto, o reconhecimento tranqüilo da sua inocência pré-ontológica.

O Verdadeiro não é apenas uma forma de pensamento, mas igualmente, um modo de existência e de vida que sejam a revelação de que "não há, para o homem bom, nenhum mal, quer na vida, quer na morte, e os deuses não descuidam do seu destino" (Platão, 1980, p. 27). O Verdadeiro não é real enquanto apenas pensado por um pensamento sem existência e que não o vive. É preciso que sejamos capazes do sacrifício de realizá-lo honestamente, existindo-o e vivendo-o segundo a renúncia de todo bem-estar, satisfação e honrarias infecundas que os infinitamente abstratos Panteões e porões das igrejas sepultam e recordam, tais como, hoje, as salas de aula fechadas e higienicamente separadas do mundo onde o ser é o seu nascer e morrer infinitos, onde o ser é trabalho e transformação, trabalho que educa e liberta, sobretudo, do vaidoso desejo de imortalidade-além de quem acredita possuir uma verdade última e definitiva, tão infértil quanto a aridez substancialista do $\mathrm{Eu}=\mathrm{Eu}$ (Ich bin Ich). Esta igualdade igual a si que se quer um ponto de partida absoluto e inultrapassável, é a negação não somente da existência e da vida como meios de acesso ao Verdadeiro, mas também, do Verdadeiro enquanto um meio de existência e de vida, que se alcança, inelutavelmente, através do aprendizado e do cultivo (Entfremdung; Entäusserung) fenomenológicos da ciência da morte enquanto saber puramente dialético e reflexivo daquilo pelo que vale a pena existir e viver, daquilo pelo que vale a pena morrer entregue ao serviço da Relação que dissolve toda estabilidade de um pretenso progresso de linearidade teleológica, e mesmo, teológica.

Eis a afirmação hegeliana da existencialidade trágica do Verdadeiro ou da sua tragicidade pós-estética como recuperação do valor da existência cujo sentido está na sua tarefa épica e sísifica de espiritualização da realidade. Tarefa que apenas em delírio e embriagado, cumpre o filósofo, através de cuja ciência, ele morre e ressuscita em seu Conceito como retiro e único templo do Real, do qual, "a aparição é o surgir e passar que não surge nem passa, mas que em si constitui a efetividade e o movimento da vida da verdade" (HEGEL, 2008, p. 53). O filósofo então vive e cultiva a efetividade e a vida da verdade que aparece e permanece sem surgir e sem passar. 
O verdadeiro é assim o delírio báquico, onde não há membro que não esteja ébrio; e porque cada membro, ao separar-se, também imediatamente se dissolve, esse delirio é ao mesmo tempo repouso transhícido e simples. Perante o tribunal desse movimento não se sustêm nem as figuras singulares do espirito, nem os pensamentos determinados; pois ai tanto são momentos positivos necessários, quanto são negativos e evanescentes (HEGEL, 2008, p. 53).

Eis a resposta à epígrafe, com a qual o nosso texto não foi muito mais que um diálogo. Nessa afirmação de que o Verdadeiro é delírio e embriaguez em sua natureza de comunidade e de tribunal, e o repousar na perda inquieta dos limites e das determinações, e assim a essencialização da evanescência, retornamos, em nossas últimas palavras, a um ponto de partida, pois, nesse texto não fizemos senão comentá-la preparando-nos cautelosamente para dizê-la a partir da análise e da compreensão das suas condições e das suas ressonâncias.

\section{CONSIDERAÇÕES FINAIS}

Esse tribunal comunitário - ou a pura manifestação da manifestação reunida a si em termos hegelianos - foi reconhecido pelo Sócrates (Platão, 1980, p. 20), filósofo que, pelo seu cultivo, alcançou a consciência-de-si moral que "sabe o seu saber como a absoluta essencialidade, ou seja, sabe o ser pura e simplesmente como a pura verdade ou [o puro] saber" (HEGEL, 2008, p. 532). Sócrates foi capaz de viver esse reconhecimento que lhe permitiu entregar-se à separação como o repouso translúcido e simples da pura reconciliação na tragicidade do sujeito que é Voz recuperada em seu arcaísmo e universalidade impessoal, uma vez que ele estava a serviço do Logos. Tarefa da qual ele recebeu o sentido da sua vida e pela qual sua morte - na medida em que ela retorna, recupera e confirma a tragicidade acolhedora do Logos - também foi uma prática comunitária do sentido, por sua vez, salvaguardada no elemento da oralidade que se fez de herança das mensagens do Retiro que nos esclarece conforme uma re-memoração (Er-innerung) do que por uma extrusão adentrou-em-si já como recém-nascido. (Hegel, 2008, p. 544). Sócrates tornou-se sujeito como essa Voz diante da qual, espontaneamente e oportunamente, ele se pôs para dela receber o juízo (Urteil) enquanto "separação originária” (ursprüngliche Teilung) característica do repouso dilacerante da Relação irrelativa. Sócrates, cuja travessia reuniu a vida e a morte em sua prática do sentido, deixou o Verdadeiro como Voz lógico-trágica e dialética e essa Voz como um tribunal no qual estamos diante de nós mesmos sem subterfúgios metafísicos e teológicos, tranqüilos com a despedida que já é retorno. 


\section{REFERENCIAS}

GABRIEL, Markus. A ideia de Deus em Hegel. Revista de Filosofia Aurora, Curitiba, v. 23, no 33, pp. 525-537, jul/dez., 2011.

GADAMER, Hans-Georg. Hegel-Husserl-Heidegger. Petrópolis: Vozes, 2012.

GUINZO, A. En torno a la filosofía de la religión de Hegel. El concepto de religión. México: Fondo de Cultura Económica, 1986.

HEGEL, G. W. F. Fenomenologia do espirito. 5. Ed. Petrópolis: Vozes: Bragança Paulista: Editora Universitária São Francisco, 2008.

HYPPOLITE, Jean. Gênese e estrutura da Fenomenologia do Espírito de Hegel. 2. Ed. São Paulo: Discurso Editorial, 2003.

MARCUSE, Herbert. Razão e revolução. Rio de Janeiro: Editora Saga, 1969.

PLATÃO. Diálogos. vol. II. Bauru: EDIPRO, 2007-2008.

Defesa de Sócrates. São Paulo: Abril Cultural, 1980.

STEIN, Sofia Inês A. O movimento dialético do conceito em Hegel: uma reflexão sobre a Ciência da Lógica. Philósophos, Goiânia, v. 7, n. 2, pp. 73-86, 2002.

VIEILHARD-BARON, Jean-Louis. O negativo em Deus e a dor infinita no pensamento de Hegel em Iena. Revista Eletrônica Estudos Hegelianos, n ${ }^{\circ}$ 5, ano 3, dezembro de 2006. Disponível em: http://www.hegelbrazil.org/revista.htm. Acesso em: 06 mar. 2013.

Recebido em 07/03/2013

Aprovado em 04/07/2013 